urban vegetation and analyzed the morphological and physiological changes in woody and herbaceous plants, their phenology and biological stability in the conditions of anthropogenic press. It is proved that the most resistant wood species in the industrial area of Kovel are common spruce, alder sticky, silver birch, ash, common maple holly, and least of all turned out to be resistant chestnut horse. Substantiated and recommended a number of plant species in order to reduce the negative impact on the environment polyutantov.

Key words: heavy metals, urbogennye factors, green plantations, accumulation.

Стаття надійшла до редколегії 16.02.2016 p.

УДК 631.53.01: 003.13: 582(477-25)

Ірина Швець, Олена Колесніченко

\title{
Насіннсва продуктивність рослин Darmera peltata (Torr. ex Benth.) Voss (Saxifragaceae) в умовах міста Кисва
}

Наведено результати дослідження особливостей насіннєвої продуктивності рослин Darmera peltata (Torr. ex Benth.) Voss у природних умовах м. Києва. Вивчено біологію цвітіння рослин D. peltata на території колекційної ділянки Ботанічного саду НУБіП України. Здійснено оцінку потенційної й фактичної насіннєвої продуктивності, визначено коефіцієнт насіннєвої продуктивності, виконано морфологічний опис насіння, визначено його масу та розміри.

Ключові слова: Darmera peltata, квітка, плід, насіння, потенційна насіннєва продуктивність, фактична насіннєва продуктивність.

Постановка наукової проблеми та її значення. Вид Darmera peltata (Torr. ex Benth.) Voss єдиний представник роду Дармера (Darmera Voss) родини Ломикаменевих (Saxifragaceae). Природний ареал виду обмежено двома американськими штатами - Каліфорнією та Орегоном (США) [8].

На сьогодні $D$. peltata відома як цінна багаторічна трав'яниста декоративна рослина, що характеризується широким ареалом інтродукції та культивується в багатьох країнах Західної й Північної Європи. Уведення в культуру D. peltata в Україні стримують недостатні відомості про біологічні властивості, онтоморфогенез та репродукційну здатність рослин.

Аналіз досліджень цієї проблеми. В умовах інтродукції міста Києва одним із важливих показників, що характеризує біологічні властивості рослин D. peltata та рівень їх адаптації до нових умов місцезростання, $€$ насіннєва продуктивність. У сучасній ботанічній літературі нами не виявлено публікацій стосовно оцінки насіннєвої продуктивності рослин D. peltata в умовах культури, тому комплексне вивчення цього питання актуальне для розробки наукових основ їх генеративного розмноження.

Мета дослідження - вивчення насіннєвої продуктивності рослин D. peltata в природних умовах міста Києва.

Об’єкт та методика дослідження. Об'єктом дослідження слугували модельні рослини D. peltata на території колекційної ділянки Ботанічного саду НУБіП України м. Києва (далі - БС НУБіП України), розміщеного в південній частині м. Києва на висоті 180 м над рівнем моря. Середня температура повітря протягом року становить $+7,3{ }^{\circ} \mathrm{C}$, найжаркішого місяця (липень) $-+20,0{ }^{\circ} \mathrm{C}$, найхолоднішого (січень) $--5,5^{\circ} \mathrm{C}$. Абсолютний максимум $-+39,4{ }^{\circ} \mathrm{C}$, абсолютний мінімум $--32,2^{\circ} \mathrm{C}$. Сума опадів на рік дорівнює 550-650 мм. Грунти темно-сірі лісові дерново-підзолисті суглинки, багаті на гумус. Дослідження відбувалося протягом 2012-2015 рр. паралельно з фенологічними спостереженнями, які проводили згідно з «Методикою фенологических наблюдений в ботанических садах СССР» [6], рекомендаціями Р. А. Карпісонової [5] та Г. М. Зайцева [4] з певними модифікаціями відповідно до біологічних особливостей росту й розвитку рослин D. peltata.

Визначення насіннєвої продуктивності здійснювали за методикою I. В. Вайнагій $[2,3]$ на основі аналізу таких морфометричних показників, як кількість суцвіть, квіток, плодів, насінних зачатків і насіння.

(C) Швець I., Колесніченко О., 2016 
Вплив несприятливих чинників навколишнього середовища на процеси росту, розвитку, цвітіння, формування й дозрівання плодів рослини зазвичай призводить до того, що тільки з частини насіннєвих зачатків формується повноцінне насіння. Саме тому, досліджуючи насіннєву продуктивність рослин D. peltata, ми виокремлювали потенційну насіннєву продуктивність (ПНП), фактичну насіннєву продуктивність (ФНП) та визначали коефіцієнт насіннєвої продуктивності (КНП). ПНП установлювали прямим підрахунком за кількістю насіннєвих зачатків у плода, а ФНП - за кількістю сформованого насіння у плода (у перерахунку на одне суцвіття). Коефіцієнт насіннєвої продуктивності розраховували за співвідношенням ПНП до ФНП, вираженим у відсотках.

Морфологічний опис насіння проводили за Артюшенко 3. Т. [1]. Масу 1000 насінин визначали за допомогою зважування на електронних вагах, розміри насіння - окулярною лінійкою мікроскопа МБС-3.

Виклад основного матеріалу й обгрунтування отриманих результатів дослідження. Нами встановлено, що квітування модельних рослин D. peltata в умовах БС НУБіП України відбувалося протягом усіх років дослідження. Починалося воно в середньому, $03,05 \pm 0,8$ за суми позитивних температур $433,7 \pm 14,4{ }^{\circ} \mathrm{C}$ та закінчувалося $14.05 \pm 2,4$ за суми позитивних температур $625,0 \pm 19,3{ }^{\circ} \mathrm{C}$. Отже, тривалість квітування рослин $D$. peltata коливалась у межах 10-14 діб.

Визначено, що квіти рослин D. peltata зібрані в китицещиткоподібний тирс, що за характером галуження належить до складних цимозних суцвіть. Порядок розкриття квіток у суцвітті - акропетальний [7].

Квітки рослин D. peltata двостатеві, актиноморфні. Квітколоже плоске, голе, гіпантій дзвоникоподібний. Чашечка п'ятичленна, зеленого кольору. Чашолистки ланцетно-еліптичної форми, завдовжки 4-6 мм, завширшки 3-5 мм. Віночок складається 3 п'яти яйцеподібних пелюсток, довжина яких - 5-8 мм, ширина - 4-6 мм, а колір варіює від білого до світло-рожевого. Діаметр квіток становить у середньому 12-18 мм. Тичинки розміщені в один ряд навколо маточки. Їх у більшості квіток рослин D. peltata 10 шт, рідше - 12-14. Маточка проста, із гладкою поверхнею. Зав'язь верхня, $2-$ 3-гніздна, багатонасінна, яйцеподібна. Тип плацентації - ламінально-латеральний. Приймочка верхівкова, проста, маленька, видовжено-лінійна, поверхня гола, блискуча, не клейка [7].

За результатами наших досліджень установлено, що плоди рослин D. peltata - 2-гніздні, рідше 3-гніздні коробочки, що стають помітними відразу після опадання пелюсток. Тривалість достигання плодів - 7-10 діб після закінчення цвітіння. Висів дозрілого насіння в середньому за роки спостережень припадає на 25.05 2,4. Одна 2-гніздна коробочка містить 35-45 насінин.

Нами визначено, що в умовах м. Києва зі збільшенням віку інтродукованих рослин D. peltata такі показники, як фактична середня кількість суцвіть та квіток на одній рослині зростає. Показники плодоутворення дуже високі й коливаються в межах 85-88 \% (табл. 1).

Таблиия 1

Ефективність плодоутворення рослин Darmera peltata (Torr. ex Benth.) Voss в умовах Ботанічного саду НУБіП України

\begin{tabular}{|c|c|c|c|c|c|c|}
\hline \multirow[b]{2}{*}{$\begin{array}{c}\text { Рік } \\
\text { дослід- } \\
\text { ження }\end{array}$} & \multicolumn{5}{|c|}{ Фактична середня кількість, ит } & \multirow[b]{2}{*}{$\begin{array}{r}\text { Плодоут- } \\
\text { ворення, \% }\end{array}$} \\
\hline & $\begin{array}{c}\text { суцвіть } \\
\text { на одній } \\
\text { рослині }\end{array}$ & $\begin{array}{c}\text { квіток } \\
\text { в одному } \\
\text { суцвітті }\end{array}$ & $\begin{array}{c}\text { плодів } \\
\text { на одному } \\
\text { суцвітті }\end{array}$ & $\begin{array}{c}\text { квіток } \\
\text { на одній } \\
\text { рослині }\end{array}$ & $\begin{array}{c}\text { плодів } \\
\text { на одній } \\
\text { рослині }\end{array}$ & \\
\hline 2012 & $1,0 \pm 0,0$ & $37,0 \pm 1,1$ & $31,6 \pm 1,2$ & $37,0 \pm 1,1$ & $31,6 \pm 1,2$ & $85,3 \pm 1,1$ \\
\hline 2013 & $1,2 \pm 0,1$ & $44,1 \pm 1,2$ & $38,0 \pm 1,6$ & $53,2 \pm 6,4$ & $46,6 \pm 6,7$ & $86,0 \pm 2,0$ \\
\hline 2014 & $1,5 \pm 0,2$ & $42,3 \pm 1,4$ & $37,0 \pm 1,4$ & $63,4 \pm 7,2$ & $55,6 \pm 6,5$ & $87,4 \pm 1,0$ \\
\hline 2015 & $1,6 \pm 0,2$ & $40,9 \pm 1,1$ & $35,6 \pm 1,2$ & $64,5 \pm 6,0$ & $56,1 \pm 5,4$ & $86,9 \pm 1,2$ \\
\hline
\end{tabular}

Квітування рослин D. peltata відбувається в травні за оптимального балансу вологи та тепла. Такі умови є сприятливим для формування генеративних органів, визрівання плодів і насіння, тому різниця між показниками ПНП та ФНП рослин D. peltata виявилася незначною. Протягом періоду досліджень нами не помічено тенденції до збільшення середньої кількості квіток у суцвітті та насіння в одному плоді у зв’язку зі збільшенням віку інтродукованих рослин (табл. 2). 
Показники насіннєвої продуктивності рослин Darmera peltata (Torr. ex Benth.) Voss у Ботанічному саду НУБіП України

\begin{tabular}{|c|c|c|c|c|c|c|}
\hline \multirow[b]{2}{*}{ Рік } & \multicolumn{3}{|c|}{ Середня кількість, ит } & \multirow[b]{2}{*}{$\begin{array}{l}\text { ПСП, } \\
\text { um }\end{array}$} & \multirow[b]{2}{*}{$\begin{array}{l}\text { ФСП, } \\
\text { шm }\end{array}$} & \multirow[b]{2}{*}{$\begin{array}{l}\text { КНП, } \\
(\%)\end{array}$} \\
\hline & $\begin{array}{c}\text { плодів на одному } \\
\text { суцвітті }\end{array}$ & $\begin{array}{c}\text { насіннсвих } \\
\text { зачатків } \\
\text { в одному плоді }\end{array}$ & $\begin{array}{c}\text { насіння } \\
\text { в одному плоді }\end{array}$ & & & \\
\hline 2012 & $31,6 \pm 1,2$ & $45,1 \pm 1,2$ & $39,6 \pm 1,1$ & $1428,7 \pm 71,9$ & $1251,8 \pm 58,4$ & $87,9 \pm 1,7$ \\
\hline 2013 & $38,0 \pm 1,6$ & $44,6 \pm 1,4$ & $38,6 \pm 1,5$ & $1690,3 \pm 78,5$ & $1463,5 \pm 78,9$ & $86,4 \pm 1,0$ \\
\hline 2014 & $37,0 \pm 1,4$ & $45,9 \pm 1,5$ & $41,8 \pm 1,3$ & $1703,6 \pm 93,0$ & $1549,6 \pm 81,7$ & $91,1 \pm 0,8$ \\
\hline 2015 & $35,6 \pm 1,2$ & $44,2 \pm 1,9$ & $40,1 \pm 1,8$ & $1573,1 \pm 85,7$ & $1427,2 \pm 77,0$ & $90,8 \pm 1,0$ \\
\hline
\end{tabular}

Коефіцієнт насіннєвої продуктивності рослин D. peltata, що характеризує життєвість виду в конкретних умовах зростання, виявився високим і досить стабільними. Його значення коливаються в межах 86-91 \% відповідно до років дослідження, що свідчить про високу здатність рослин D. peltata пристосовуватися до нових умов існування в культурі.

Проведений порівняльний аналіз насіннєвої продуктивності за роками свідчить про те, що одночасно зі збільшенням віку рослин спостерігаємо підвищення потенційної та фактичної насіннєвої продуктивності рослин $D$. peltata за рахунок розростання кореневища й збільшення кількості суцвіть і квіток у кожної рослини (рис. 1).

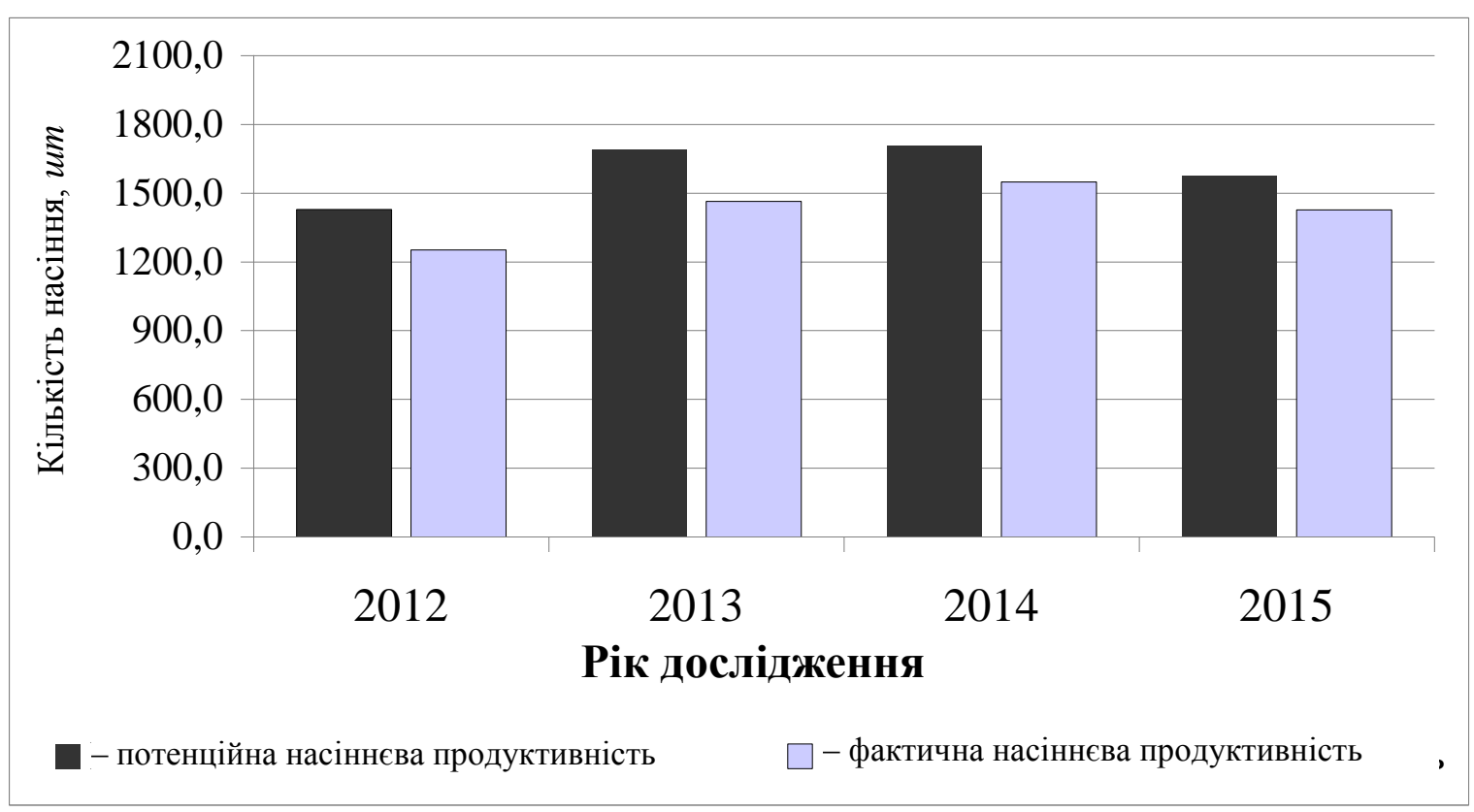

Рис. 1. Динаміка росту насіннєвої продуктивності рослин Darmera peltata (Torr. ex Benth.) Voss у Ботанічному саду НУБіП Украӥни

Маса 1000 насінин варіює в межах 0,13-0,17 г, в 1 г їх нараховується близько 5882-7692 шт. Під час досліджень нами не виявлено тенденції до збільшення середньої маси насіння (табл. 3).

Таблиия 3

Маса насіння рослин Darmera peltata (Torr. ex Benth.) Voss в умовах Ботанічного саду НУБіП України

\begin{tabular}{|c|c|c|c|c|}
\hline \multirow{2}{*}{ Показник } & \multicolumn{4}{|c|}{ Рік дослідження } \\
\cline { 2 - 5 } & $\mathbf{2 0 1 2}$ & $\mathbf{2 0 1 3}$ & $\mathbf{2 0 1 4}$ & $\mathbf{2 0 1 5}$ \\
\hline Маса 1000 насінин, 2 & $0,132 \pm 1,1$ & $0,174 \pm 0,7$ & $0,151 \pm 2,4$ & $0,147 \pm 1,3$ \\
\hline
\end{tabular}


Насіння рослин D. peltata за формою клиноподібне, за розміром - дрібне, завдовжки 1,32-1,56 мм. Поверхня насінини гола, слабо-блискуча, дрібно-горбиста, світло-коричнева, без придатків (рис. 2).

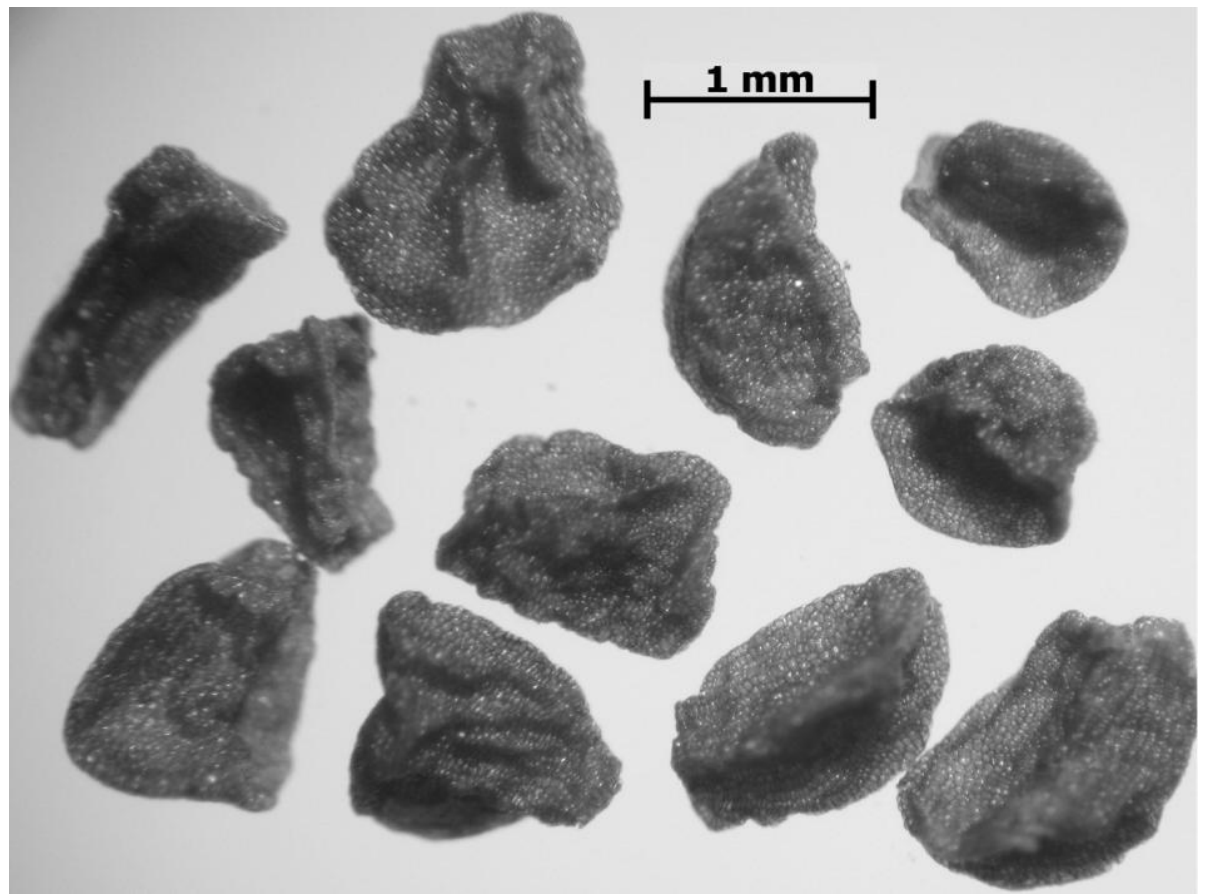

Рис. 2. Форма та розміри насіння рослин Darmera peltata (Torr. ex Benth.) Voss (фото автора)

Наявність життєздатного насіння рослин $D$. peltata - невід'ємна умова виживання рослин і розширення культурного ареалу.

Висновки та перспективи подальшого дослідження. Отримані нами результати досліджень свідчать про можливість насіннєвого розмноження та успішного вирощування рослин-інтродуцентів D. peltata у природно-кліматичних умовах міста Києва. Це сприятиме збільшенню асортименту декоративно-листяних і красиво квітучих рослин для формування системи зелених насаджень міста Києва.

\section{Джерела та література}

1. Артюшенко 3. Т. Атлас по описательной морфологии высших растений. Семя / 3. Т. Артюшенко. - Л. : Наука, 1990. - 204 с.

2. Вайнагий И. В. Методика статистической обработки материала по семенной продуктивности растений на примере Potentilla aurea L. / И. В. Вайнагий // Раст. ресурсы. - 1973. - Т. 9, № 2. - С. 287-296.

3. Вайнагий И. В. О методике изучения семенной продуктивности растений / И. В. Вайнагий // Ботан. журн. 1974. - Т. 59, № 6. - С. 826-831.

4. Зайцев Г. Н. Фенология травянистых многолетников / Г. Н. Зайцев. - М. : Наука, Главный ботанический сад (Академия наук СССР), 1978. - 97 с.

5. Карписонова Р. А. Методика фенологических наблюдений за травянистыми многолетниками в отделе флоры СССР ГБС АН СССР / Р. А. Карписонова // Методика фенологических наблюдений в ботанических садах СССР : сб. ст. - М. : Изд-во ГБС АН СССР, 1972. - С. 47-52.

6. Методика фенологических наблюдений в ботанических садах СССР - М. : Изд-во АН СССР, 1975. - 27 с.

7. Федоров, А. А. Атлас по описательной морфологии высших растений. Соцветие / А. А. Федоров, 3. Т. Артюшенко. - Л. : [б. и.], 1979. - 294 с.

8. Kubitzki K. The Families and Genera of Vascular Plants (Book 9) / K. Kubitzki, C. Bayer, P. F. Stevens. Hamburg : Springer, 2006. -509 p.

Швец Ирина, Колесниченко Елена. Семенная продуктивность растений Darmera peltata (Torr. ex Benth.) Voss (Saxifragaceae) в условиях города Киева. В условиях интродукции города Киева одним из важных показателей, характеризующих биологические свойства растений Darmera peltata (Torr. ex Benth.) Voss и их уровень адаптации к новым условиям произрастания, является семенная продуктивность. Изучение данного вопроса является актуальным для разработки научных основ их генеративного размножения. 
Приведены результаты исследования особенностей семенной продуктивности растений D. peltata в естественных условиях г. Киева. Исследована биология цветения растений D. peltata на территории коллекционного участка Ботанического сада НУБиП Украины. Осуществлена оценка потенциальной и фактической семенной продуктивности, определен коэффициент семенной продуктивности, предоставлено морфологическое описание семян, определены его масса и размеры.

Полученные нами результаты исследований свидетельствуют о возможности семенного размножения и успешного выращивания растений-интродуцентов D. peltata в природно-климатических условиях Киева. Это будет способствовать увеличению ассортимента декоративно-лиственных и красиво цветущих растений для формирования системы зеленых насаждений города Киева.

Ключевые слова: Darmera peltata, цветок, плод, семена, потенциальная семенная продуктивность, фактическая семенная продуктивность.

Shvets Iryna, Kolesnichenko Elena. Seed Productivity of Plants Darmera peltata (Torr. ex Benth.) Voss (Saxifragaceae) in Conditions of Kiev. In conditions of introduction of Kyiv one of the important indicator which characterizing the biological properties of plants Darmera peltata (Torr. Ex Benth.) Voss and their level of adaptation to the new environment habitat is seed production. The learning of this issue is relevant for the development of scientific bases of generative reproduction.

The results of research the features of seed productivity the plants D. peltata in natural conditions of Kyiv is given. Studied the biology of flowering plants of $D$. peltata on the collection plot of Botanical Garden NULES of Ukraine. Results of estimation of potential and real seed productivity are resulted, defined coefficient of seed production, results of study the morphological description of seeds, their mass and size also is given.

Our results of research show the possibility of seed breeding and successful cultivation plants of D. peltata in climatic conditions in Kyiv. It will increase the range of decorative hardwood and beautifully-flowering plants to create a system of green spaces in Kyiv.

Key words: Darmera peltata, flower, fruit, seeds, potential seed productivity, real seed productivity.

Стаття надійшла до редколегії 06.03.2016 p.

УДК 712.253:581(477)

Анастасія Власенко

\section{Оцінка декоративності дендросозоекзотів еx situ Степу України}

У статті проаналізовано сучасні методики оцінки декоративності деревних рослин, на основі чого розроблено оригінальну шкалу комплексної оцінки, яку апробовано на 30 видах дендросозоекзотів ех situ, що охороняються на територіях природно-заповідного фонду Степу України.

Ключові слова: оцінка декоративності, дендросозоекзоти, ex situ, Степ України.

Постановка наукової проблеми та її значення. Нині існують різноманітні методики та шкали оцінки декоративності дерев і чагарників. Здебільшого вони грунтуються на якісних показниках сезонного розвитку рослин у цілому та окремих його стадій. Під час оцінки декоративності дендросозоекзотів ex situ штучних заповідних парків Степу України ми зіткнулися з труднощами застосування деяких загальноприйнятих методик і шкал комплексної оцінки декоративності деревних рослин [17; 16; 36]. Через значну кількість досліджених видів [5] дендросозоекзотів виникла потреба окреслити вибірку найраритетніших видів рослин. Відібрані види часто ростуть на територіях різних ботанічних садів, що ускладнює сезонну оцінку декоративних ознак рослин через значну віддаленість між ними. Особливості природних умов штучних заповідних парків зумовлюють набування рослинами одного й того самого виду відмінних зовнішніх декоративних ознак. Також більшість запропонованих шкал комплексної оцінки декоративності деревних рослин тією чи іншою мірою варто використовувати для оцінки ознак рослин певної біоморфологічної групи. Екзотична дендросозофлора ex situ штучних заповідних парків Степу України включає види чотирьох типів життєвих і сезонних форм деревних рослин: листяних та хвойних, листопадних і зимовозелених [6], що, безперечно, ускладнює оцінку декоративності для всіх видів дендроекзосозофлори дослідженого регіону за однією методикою.

(C) Власенко А., 2016 